\title{
COGNITIVE SCIENCES FOR ACADEMIC SUCCESS OF MIDDLE SCHOOL STUDENTS
}

\author{
Pauline Allix ${ }^{1}$, Amélie Lubin ${ }^{1,2}$, Céline Lanoë ${ }^{1}, \&$ Sandrine Rossi ${ }^{1}$ \\ ${ }^{1}$ Laboratoire de Psychologie Caen Normandie, Normandie Univ, UNICAEN, LPCN (EA 7452), \\ 14000 Caen (France) \\ ${ }^{2}$ Université Paris Descartes, Sorbonne Paris Cité, Institut de Psychologie, Paris (France)
}

\begin{abstract}
Territorial vulnerabilities subdue children at risk of difficulties at school in the Normandy region. We examined benefits of a personalized accompaniment based on the cognitive sciences on academic success of middle school students. We recruited middle school 6th graders students in Normandy. The experimental college included 52 students who benefited from pedagogical program based on cognitive sciences, was compared to the control college included 48 students who received classic pedagogical program of methodology. All students were interviewed before and after one year of teaching. We used the Children Memory Scale (Cohen, 2001) to assess students' attention and national tests to assess academic performance in reading comprehension and numeracy. Students were assigned a global score for each test. We conducted repeated-measures analysis of variance for each global score. We observed significant interaction between Group (experimental vs. control) and Test (Pre- vs. Post-test) on attention and on numeracy global score considering age as covariable in analysis. The results showed that the pedagogical program based on cognitive sciences significantly improves students' attention and enhances performances improvement of $6^{\text {th }}$ graders in numeracy after one year of implementation compared to a classic pedagogical program. Our proposed pedagogical program seems to be one of the possible levers to promote the success of all middle school students while promoting a scientific approach to evaluating educational practices.
\end{abstract}

Keywords: Cognitive science, academic success, learning, neuroeducation.

\section{Introduction}

In France, there is more and more students who do not have basic skills in reading comprehension, numeracy or science (Commission européenne, 2017). Social and territorial vulnerabilities subdue children at risk of difficulties or failure at school, particularly in Normandy (Boudesseul et al., 2016 ; Direction de la recherche, des études, de l'évaluation et des statistiques, 2018). The French reform of the Middle School is in line of the context of poor academic performance and one of its objectives is "to enable all students to learn to learn" through personalized accompaniment. One of challenges of this reform is to provide tools for teachers that will enable students to achieve this objective. Cognitive sciences could take up this challenge. This field of research focuses on the fundamental processes that underlie successful school learning (Goswami, 2006) and can help to modulate educational strategies and redesign educational programs to optimize learning for the success of all students (Howard-Jones et al., 2016). One of the proposals is to include teachings based on brain functioning in school curricula (Dommett, et al., 2013 ; Gaskins \& Pressley, 2007 ; Rossi, et al., 2017). Few studies have shown the benefits of this type of curricula on intelligence theories or student academic performance (Blackwell, Trzesniewski, \& Dweck, 2007; Dommett et al., 2013; Lanoë, Rossi, Froment, \& Lubin, 2015). However, these curricula are short-term and, to our knowledge, there are no longer-term curricula available. Our study aims to evaluate the benefits of a long-term curricula based on cognitive science extended over two years for Middle School 6th graders students in France. The underlying hypothesis is that a better understanding of its cognitive and neurocognitive functioning in a school learning context can enable all students to make the most of their potential. We presented results after one year of instruction. 


\section{Method}

One hundred Middle School 6th graders students from Normandy participated to the study. The experimental Middle School included 52 students ( $m=11 ; 4$ years; $s d=3$ months; 23 girls) who benefited from curricula based on cognitive sciences, was compared to the control Middle School included 48 students ( $m=11 ; 3$ years; $s d=6$ months; 19 girls) who received classic curricula based on learning methodology. These curricula take place within personalized accompaniment, which are part of the official programs of the Ministry of National Education. Students were matched in terms of age, sex and socioeconomic level. Every student and his/her parents gave their written consent to participate to the study. All students were native speakers of French, and none of them reported cognitive impairments or developmental problems.

In the experimental Middle School, students received instruction based on cognitive science. This instruction focused on anatomy and brain plasticity, attention, memory, executive functions, work methods that promote learning, and healthy living. The content of the curricula was built by the teachers who were trained in cognitive sciences beforehand by researchers. Then, the content of the curricula was validated by the researchers' team of Laboratory of Psychology of Caen Normandy. In the control Middle School, students received a classic instruction of methodology. The content focuses on helping students organize themselves and know when and how to learn. All student received curricula at the rate of one 45-minutes weekly session for two years (2017-2019). All students were interviewed before (Pre-test) and after one year of instruction (Post-test) to assess the benefits of the pedagogical program based on cognitive science. We used the Attention/Concentration index (between 50 and 150) of the Children Memory Scale (Cohen, 2001) to assess students' attention. We used national tests to assess academic performance in reading comprehension and numeracy created by the Academic Centre of Research Development of Innovation Experimentation from Caen. The reading comprehension test assed information selection, implicit deduction, and identification of a chronology. The numeracy test assed number comprehension, calculation, and arithmetic word problem solving.

\section{Results}

We conducted general linear model with the Group as the between factor (experimental vs. control), the Test as within factor (Pre-test vs. Post-test) and Age as covariable. We observed significant interaction between Group and Test on Attention/Concentration index $\left(F_{(1 ; 97)}=16.05 ; p<.0001\right.$; $\eta_{p}{ }^{2}=.14$ ) (Figure 1). The results showed that the attention/concentration index in the experimental group was significantly higher in the Post-test than in the Pre-test $\left(m_{\text {Pre-test }}=88.94 ; m_{\text {Post-test }}=97.67\right)$, whereas it seems that it was unchanged for students in the control group $\left(m_{\text {Pre-test }}=93.79 ; m_{\text {Post-test }}=92.56\right)$. We did not observe any significant effect on reading comprehension global score. We observed significant interaction between Group and Test on numeracy global score $\left(F_{(1 ; 97)}=8.46 ; p<.005 ; \eta_{p}{ }^{2}=.08\right)$ (Figure $2)$. The results showed that performances of students in both groups significantly improved, but improvement is more important for students in the experimental group $\left(m_{\text {Pre-test }}=7.43 / 20\right.$; $\left.m_{\text {Post-test }}=10.26 / 20\right)$ than for students in the control group $\left(m_{\text {Pre-test }}=9.15 / 20 ; m_{\text {Post-test }}=10.65 / 20\right)$, performances of two groups were different in pre-test.

Figure 1. Attention/Concentration index according to the Group and the Test.




Figure 2. Numeracy global score according to the Group and the Test.

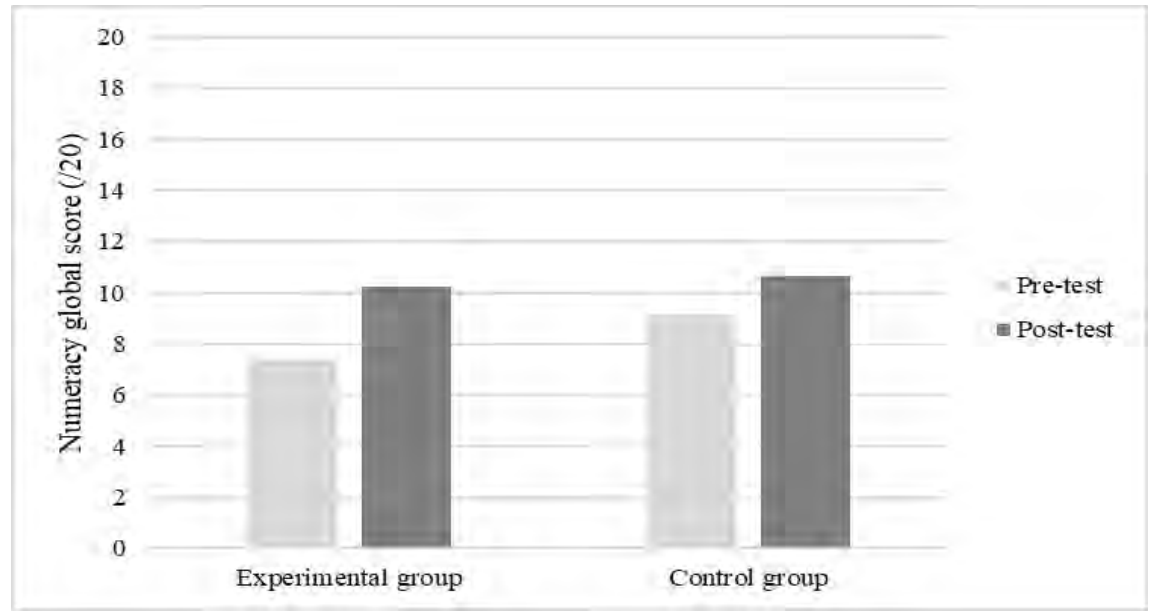

\section{Conclusion}

The results showed that the curricula based on cognitive sciences significantly enhances performances improvement of $6^{\text {th }}$ graders in numeracy after one year of implementation compared to a classic curricula. It seems that students appropriated knowledge taught, assimilated their active role in their learnings and may be applied its in school learning, here evaluated in reading comprehension and numeracy. Nevertheless, it remains necessary for the curricula to take place over two consecutive years to consolidate these initial benefits and observe other effects affecting other areas of cognitive functioning and learnings. Our proposed curricula seems to be one of the possible levers to promote the success of all Middle School students while promoting a rigorous and scientific approach to evaluating educational practices.

\section{References}

Blackwell, L. S., Trzesniewski, K. H., \& Dweck, C. S. (2007). Implicit theories of intelligence predict achievement across an adolescent transition: A longitudinal study and an intervention. Child development, 78(1), 246-263. https://doi.org/10.1111/j.1467-8624.2007.00995.x

Boudesseul, G., Caro, P., Grelet, Y., Minassian, L., Monso, O., \& Vivent, C. (2016). Atlas des risques sociaux d'échec scolaire: l'exemple $d u$ décrochage, France métropolitaine et DOM (Céreq/MENESR-DEPP, Vol. 2).

Cohen, M. J. (2001). CMS: échelle de mémoire pour enfants. Paris: Editions du Centre de Psychologie Appliquée.

Commission européenne (2017). Rapport de suivi de l'éducation et de la formation 2017 - France.

Direction de la recherche, des études, de l'évaluation et des statistiques (2018). Les conditions de vie des enfants en France métropolitaine.

Dommett, E. J., Devonshire, I. M., Sewter, E., \& Greenfield, S. A. (2013). The impact of participation in a neuroscience course on motivational measures and academic performance. Trends in Neuroscience and Education, 2(3), 122-138. https://doi.org/10.1016/j.tine.2013.05.002

Gaskins, I.W., \& Pressley, M. (2007). Teaching metacognitive strategies that address executive function processes within a schoolwide curriculum. In L. Meltzer (Ed), Executive function in education: from theory to practice (pp. 261-286). New-York: The Guilford Press.

Goswami, U. (2006). Neuroscience and education: from research to practice? Nature reviews neuroscience, 7(5), 406-413. https://doi.org/10.1038/nrn1907

Howard-Jones, P. A., Varma, S., Ansari, D., Butterworth, B., De Smedt, B., Goswami, U., Thomas, M. S. (2016). The principles and practices of educational neuroscience: Comment on Bowers (2016). Psychological Review, 123, 620-627.

Lanoë, C., Rossi, S., Froment, L., \& Lubin, A. (2015). Le programme pédagogique neuroéducatif «À la découverte de mon cerveau»: quels bénéfices pour les élèves d'école élémentaire? A.N.A.E., (134), 1-8.

Rossi, S., Lubin, A., \& Lanoë, C. (2017). Découvrir le cerveau à l'école. Les sciences cognitives au service des apprentissages. Paris: Canopé Editions, Ministère de l'Education Nationale 